\title{
MSMEs: The Key to Entrepreneurship Development in India
}

\author{
Dr.K. Alamelu and R. Baskaran
}

\begin{abstract}
The term MSME means micro, small, and medium enterprises; SME means small and medium enterprises; while MSE means micro and small enterprises. In India, the Micro, Small, and Medium Enterprises Development (MSMED) Act 2006 defines MSMEs. It introduces the concept of 'enterprise' as opposed to the earlier concept of industry. The overall contribution of small firms-formal and informal-to the GDP and employment remain about the same across low, middle, and high-income group countries. As income increases, the share of the informal sector decreases and that of the formal SME sector increases. The main need is to generate large scale employment as countries develop the share of agriculture in providing employment and in GDP decreases. The MSME sector in India is heterogeneous, dispersed, and mostly unorganized. It includes diverse types of production units ranging from traditional crafts to high-tech industries. In this regard, the core challenges of MSMEs are the following; Inadequate Access to Credit and Working Capital, Dwindling of a Vibrant Sector, Non-Availability of Quality Raw Materials and Packaging Facilities on a Timely Basis, Insufficient Market Research, Linkages \& Design Inputs, Rehabilitation of Sick SSI Units, Globalization, and Technology Upgradation and Achieving 'Economies of Scale'. At present, there is no subsector target for the MSE sector within the overall stipulated $40 \%$ ceiling for the priority sector lending. Since sub-targets have already been fixed at $18 \%$ for agriculture and at 10\% for the weaker sectors, the MSE sector has to compete with real estate, housing, education, retail, etc. for the remaining $12 \%$.
\end{abstract}

Keyword--- Economies of Scale, MSMED, GDP, MSMEs

\section{INTRODUCTION}

$\mathrm{A}$ $\mathrm{N}$ entrepreneur is the one, entering into adventurous, bold, daring, initiative, resourceful, risky new actions/ launching new ventures, new business/ industry, accepting full Responsibility for its outcomes. The term was originally a loan-word from French and was first defined by the IrishFrench economist Mr. Richard Cantillon and coined by a French economist in the 19th century. The Entrepreneur is a centre-premier of all factors of Production, ensuring optimal utilization of available economic resources for higher productivity and greater yield.

Dr.K. Alamelu, Associate Professor, Department of Bank Management, Alagappa University, Karaikudi.E-mail: alakkn@gmail.com

R. Baskaran, Research Scholar, Alagappa University, Karaikudi. E-mail: subbaskaran@yahoo.com/subbaskaran@gmail.com

\section{Definition of Micro, SMALl ANd Medium ENTERPRISES IN INDIA}

The term MSME means micro, small, and medium enterprises; SME means small and medium enterprises; while MSE means micro and small enterprises. There is no globally accepted definition of MSMEs. Different countries use different criterion; most of the definitions are based on investment ceiling and number of people employed.

According to a World Bank research paper, 54 countries define SMEs as enterprises employing no more than 200-300 people. These include 13 low-income, 24 middle-income, and 17 high-income countries. Most African countries use a cutoff of 200 employees; Japan uses 300 employees. The definition of Micro, small and medium enterprises as per MSMED Act, 2006 is based on their investment in plant and machinery (for manufacturing enterprise) and on equipment for enterprises providing or rendering services, as noted herein below.

Table 1: Classification of Manufacturing Enterprises

\begin{tabular}{|c|c|c|}
\hline Classification & $\begin{array}{c}\text { Manufacturing } \\
\text { Enterprises* }\end{array}$ & $\begin{array}{c}\text { Service } \\
\text { Enterprises** }^{* *}\end{array}$ \\
\hline Micro & $\begin{array}{c}\text { Rs.2.5 million / } \\
\text { Rs.25 lakh }\end{array}$ & $\begin{array}{c}\text { Rs.1 million / } \\
\text { Rs.10 lakh }\end{array}$ \\
\hline Small & Rs.50 million / Rs.5 & Rs.20 million / \\
& crore & Rs.2 crore \\
\hline Medium & Rs 100 million / & Rs.50 million / \\
& Rs.10 crore & Rs.5 crore \\
\hline
\end{tabular}

Source: $11^{\text {th }}$ Five Year Plan

The term "village industries" has been redefined in amended KVIC, Act, 1956 as "any industry located in a rural area which produces any goods or renders any service with or without the use of power and in which the fixed capital investment per head of artisan or worker does not exceed Rs. One lakh (Rs. one lakh and fifty thousand in case of village industry located in a hilly area) or such other sum as may, by notification in the Official Gazette, be specified from time to time by the Central Government".

\section{ROLE OF MSMES IN GLOBAL ECONOMY}

The overall contribution of small firms-formal and informal - to the GDP and employment remain about the same across low, middle, and high-income group countries. As 
income increases, the share of the informal sector decreases and that of the formal SME sector increases.

In Brazil, MSEs represent $20 \%$ of the total GDP. Of the country's 4.7 million registered businesses, $96.8 \%$ are MSEs and-along with the other 9.5 million informal enterprisesthey employ 59\% of the economically active population. Similarly, informal and micro enterprises account for 39\% of labour force and contribute to $24 \%$ of the GDP in South Africa; SMEs employ $27 \%$ of the labour force and contribute $32 \%$ to the GDP; while large enterprises employ $34 \%$ people and account for $44 \%$ of GDP.

China has created more SMEs in the last 20 years than the total number of SMEs in Europe and the US combined. It increased from about 1 million private sector SMEs in the 1990s to 40 million in 2004. In China, an industrial SME is defined as having up to 2000 employees, while a small business has less than 300 employees and a medium-size business has employees between 301 and 2000. The Act also provides for a statutory consultative mechanism at the national level with a balanced representation of all the sections of stakeholders and with a wide range of advisory functions. Establishment of specific funds for promotion, development, and enhancement of the competitiveness of these enterprises; notification of schemes/ programmes, progressive credit policies and practices; preference to products and services of MSEs in the government procurement; more effective mechanisms for mitigating the problems of delayed payments; and a scheme for easing the closure of business by these enterprises are some features of the Act.

Table 2: Definition of MSMEs as per Micro, Small and Enterprises Act 2006

\begin{tabular}{|l|l|}
\hline \multicolumn{2}{|c|}{ Manufacturing Sector } \\
\hline Enterprises & $\begin{array}{l}\text { Investment in Plant and machinery } \\
\text { (original cost excluding land and building } \\
\text { and the items specified by the then } \\
\text { ministry of small scale industries, vide its } \\
\text { notification No. S.O.1722 (E) dated 5 } \\
\text { October 2006) }\end{array}$ \\
\hline Micro Enterprises & Does not exceed Rs. 25 Lakhs \\
\hline Small Enterprises & $\begin{array}{l}\text { More than Rs. 25 Lakhs and less than Rs. } \\
\text { 10 Crore. }\end{array}$ \\
\hline Medium Enterprises & $\begin{array}{l}\text { More than Rs. 5 Crore and Less than Rs. } \\
10 \text { Crore }\end{array}$ \\
\hline Service Sector & Investment in Equipments \\
\hline Enterprises & Does not exceed Rs. 10 Lakhs \\
\hline Micro Enterprises & $\begin{array}{l}\text { More than Rs. 10 Lakhs and less than Rs. } \\
\text { 2 Crore. }\end{array}$ \\
\hline Small Enterprises & $\begin{array}{l}\text { More than Rs. 2 Crore and less than Rs. 5 } \\
\text { Crore }\end{array}$ \\
\hline Medium Enterprises
\end{tabular}

Source: $11^{\text {th }}$ Five Year Plan

\section{NEED FOR GREATER ENGAGEMENT WITH MSES}

The main need is to generate large scale employment as countries develop the share of agriculture in providing employment and in GDP decreases. According to the Australian Economist Chris Hall, the SMEs contribute about
$70 \%$ of net new jobs across the globe, while larger firms tend to be job destroyers.

Among the MSEs in India, the dispersed food products sector generates maximum employment $(13.7 \%$ of total employment in the MSE sector), followed by non-metallic mineral products $(10.9 \%)$ and metal products $(10.2 \%)$. In chemicals and chemical products, machinery parts except electrical parts, wood products, basic metal industries, paper products and printing, hosiery and garments, repair services, and rubber and plastic products, the contribution ranges from $9 \%$ to $5 \%$.

The presence of MSEs across States is not uniform. Tamil Nadu (14.5\%) makes the maximum contribution to employment followed by Maharashtra (9.7\%), Uttar Pradesh (9.5\%), and West Bengal (8.5\%). Per unit employment is high-17, 16, and 14, respectively - in Nagaland, Sikkim, and Dadar \& Nagar Haveli; Madhya Pradesh has the lowest figure of 2 . In all other cases it is around 6.

\section{Challenges of MSME SECTOR}

The MSME sector in India is heterogeneous, dispersed, and mostly unorganized. It includes diverse types of production units ranging from traditional crafts to high-tech industries. Yet, it is often considered to be limited to large units among the SSIs which deal with high-tech industries or serve as ancillaries to large industries. Segments such as power-looms, handlooms, handicrafts, food processing, coir, sericulture, khadi, village industries, and wool, which are mostly unorganized, are fragmented across various ministries and often seen only as rural livelihoods. This is, however, far from the truth. Towns and cities such as Benaras, Berhampur, etc., are big handloom centres; Lucknow, Bhopal, Delhi, and Jaipur are famous for their handicraft products while powerlooms are normally only found in urban areas.

Thus money is held up, further impoverishing the workers. The MSEs engaged in manufacturing of products such as paints, dyes and chemicals, explosives, minerals, leather and leather goods, etc., pollute the environment. These units have to obtain non-pollution certification from the concerned pollution control agencies of the State.

In this regard, the core challenges of MSMEs are the following;

- Inadequate Access to Credit and Working Capital

- Dwindling of a Vibrant Sector

- Non-Availability of Quality Raw Materials and Packaging Facilities on a Timely Basis

- Insufficient Market Research, Linkages \& Design Inputs

- Rehabilitation of Sick SSI Units

- Globalization

- Technology Upgradation and Achieving 'Economies of Scale' 


\section{EleVenth Plan Strategies For Promotion of MSES}

The current Eleventh Plan approach to the MSE sector marks a shift from the welfare approach to that of empowerment. The Plan looks at this sector as an engine for sustained and inclusive economic growth and employment. The strategy is two-pronged - it focuses on livelihood and social security. This is not just a rights issue but also makes economic common sense artisans and entrepreneurs can be most productive only when they are physically and mentally fit. The Plan considers the MSE sector as an important segment of industry which is unorganized and hence needs support and access to all schemes of industry with special enabling provisions. As it is, Tribal Sub-Plan (TSP) and Special Component Plan (SCP) are constitutional requirements. Support for women's empowerment and minority development has been stressed upon in the Prime Minister's 15-point programme and in other flagship schemes of the government.

The effort during the Plan period will therefore be to organize this sector, to create clusters and SHGs of weavers/artisans to improve their bargaining power and to enable them to pool resources. These groups, comprising weavers, artisans, and entrepreneurs, will be given full control over cluster decisions and will be provided support in the form of credit, inputs, expertise, and marketing links. The Working Group on MSMEs for the Eleventh Plan had projected the need for Rs 296400 crores as the working capital and term loans for MSEs during the Eleventh Plan.

For micro and small entrepreneurs who cannot bring in sufficient equity/promoter's contribution, a flexible debtequity ratio may need to be adopted while sanctioning export credit. Banks will be encouraged to ensure that all loans upto Rs 5 lakh to MSEs (excluding credit from MFIs) are given free of collateral at the interest rate of $8 \%$. Coverage under the Credit Guarantee Trust Fund will be increased. As international experience indicates cluster based financing is the most effective way of providing credit to MSEs, 100 MSE clusters based on the PPP model will be adopted on a pilot basis.

During the current Eleventh Plan period, an aggressive marketing campaign using the media and icons has been launched. Handlooms, handicrafts, food processing, and other cultural industries will be linked to tourism; circuits for heritage and fabric tourism will be developed. In the West, the cultural industries have become the most rapidly growing sector in the world, contributing over 7\% of the world's GDP. Giving an 'industry' status to crafts-persons is important because it entitles them to tax benefits and export promotion schemes, makes them eligible for banking and credit support, and helps them lobby for protection of intellectual property.

\section{CONCLUSION}

The definition/ meaning of entrepreneurship has been radically changing, with the course of time, according to the changes in world's economic structure and becoming too complex to say so particularly and precisely. However it is now or it transforms now and then, Let us "entertain the premier show = entrepreneurship". Let us grow and stand it up and of course it will grow and standardize every one of us in the form of per capita income and overall economic growth of nation. The total number of units of MSMEs is much more than that of large scale industries globally. Every enterprise or entrepreneur is a staircase of economic ladder as the every unit is a link of economic chain. The ladder and the chain need to be stronger. Otherwise, neither we (our country) can climb up nor we can tie up our issues with the chain. Therefore, without strengthening them, the Indian Economy cannot be (come) stronger. The entrepreneurship is an entry gate of any Economy. Its opening and closing will certainly create some impacts on the economy. The entrepreneurship is an axis on which the global economy itself revolves. Small Drops make ocean. Likewise, the MSMEs, make a bigger economy. Therefore we can conclude herewith simply saying that "No Entrepreneurs, No Economy".

Table 3: Year-wise Physical Targets for the Eleventh Plan Source: $11^{\text {th }}$ Five Year Plan

\begin{tabular}{|c|c|c|c|c|c|c|}
\hline Item & $\mathbf{2 0 0 7 - 0 8}$ & $\mathbf{2 0 0 8 - 0 9}$ & $\mathbf{2 0 0 9 - 1 0}$ & $\mathbf{2 0 1 0 - 1 1}$ & $\mathbf{2 0 1 1 - 1 2}$ & CAGR \\
\hline $\begin{array}{c}\text { Production at Current Price (Rs. } \\
\text { Crore) }\end{array}$ & 682613 & 816705 & 977144 & 1169112 & 1398803 & $15.4 \%$ \\
\hline Employment (In Lakh Persons) & 322.28 & 338.39 & 355.31 & 373.08 & 391.73 & $4 \%$ \\
\hline
\end{tabular}

